\title{
THE CENTRAL INTELLIGENCE AGENCY: AN INSTRUMENT OF POLITICAL EDUCATION
}

American citizens are discovering that education in international affairs is like education general$\mathrm{ly}-\mathrm{it}$ is a desirable and sometimes exhilarating process, but it can also be painful. As ignorance gives way to knowledge, as the clear black and white patterns merge into varying shades of gray lacking sharp distinction, a simplistic approach to international problems must be replaced by more sophisticated understanding of the limitations and possibilities open to those with power and authority.

This education in international affairs reminds us that we are far from living in the best of all possible worlds, and forces an acceptance, however reluctant, that all nations including our own engage deliberately and professionally in some very ursavory affairs. A good example, if not the most significant, is provided by the activities of the American Central Intelligence Agency. For an agency whose value depends in large part on keeping its activities covert, it has received in recent years an undue number of headlines. But in spite of the public attention the G.I.A. has received we can assume that, like the iceberg, the greater proportion lies well below eye level.

The role of the C.I.A. in the 1953 coup against Mossadegh in Iran, the 1954 assault against the Arbenz government of Guatemala, the $1958 \mathrm{re}$ volt against Sukarno in Indonesia-the role of the C.I.A. in these and other serious affairs did little to stir the general American public. For many American citizens the first real awareness of what falls under the purview of an intelligence gathering agency came from the flap over the U-2.

Did the United States really send secret llights over the territory of a state with which it was not at war? Our initial, automatic denial was quickly countered by the Russians who displayed proof for their assertion that indeed we did and they didn't like it. And then President Eisenhower, in an act unprecederted for a head of state, claimed knowledge of and responsibility for the lights. The innocents who were shocked by this were condescended to or simply dismissed by those who had long accepted as necessary the activities of the C.I.A. But these innocents comprised a good part of the nation and for them it was a painful step in their political education.

The next celebrated exposure of the C,I.A. resulted from the debacle of the Bay of Pigs. This was a failure of such grand proportions that it taught the President as well as the citizenry something about the C.I.A. Our recent unsatisfactory intervention in the Dominican Republio indicates that there is something yet to be learned.

The American public has, then, undergone a gradual education in the extent and purpose of covert intelligence agencies and was not wholly surprised when the now recognized ritual was played out with Singapore's Prime Minister, Lee Kuan Yew: Mr. Lee charged that the C.I.A. had attempted to buy state secrets in Singapore some years ago, that the agent had been arrested, and that the C.I.A. had attempted to buy Mr. Lee's silence with a bribe; the State Department immediately denied the charge; the Prime Minister released a letter, dated April 16, 196I, from Dean Rusk apologizing for "improper activities" of U.S. officials in Singapore; the State Department then admitted the incident, explaining that the earlier denial had come from an official unacquainted with the incident. There was in all this an implication that the C.I.A. had misled the State Department when it had attempted to check back on the incident.

Mr. Lee's disclosures and his fulminations have subsequently been dismissed as unimportant and have been attributed to irritation at an imagined personal slight or as an attempt to 
show Singapore as a clearly independent country. But they remain important for what they tell us about the C.I.A. ahd its relation to offcial, declared policies of our government.

Any country-certainly one as powerful as the United States-can readily admit and absorb the damage inflicted by several such disclosures. But 4 series of them does damage that may not easily be repaired. Future denials of U.S. intervention in the affairs of any particular state will carry loss weight not only in the other countries but here at home. Statements from our State Department will be received with a degree of skepticism. The real accomplishments of our intelligence agencies will be offset by the equally real harm that is done to our management of foreign affairs. And the existent worry that the C.I.A not only carries out policy directives but does on oecasion suggest and make policy will increase.
These are legitimate concerns for every citizen. If there is a danger that naive and uninformed citizens would attempt to put a precipitate and premature halt to some activities of the C.I.A., there is another danger that informed and sophisticated observers may too readily accept the widespread engagement of intelligence agents in affairs of policy as the price we must pay to maintain our national interests. This is an area where the instinctive hesitation of the average citizen to accept clandestine behavior and his repugnance for some of the less attractive aspects of covert activities should not readily be dismissed. If the gap between the goals we profess to seek and means we use to seek them grows too wide, it will weaken the citizens' trust in their own government, and without such trust even a strong state cannot well survive the crises that it must inevitably face.

J. F.

\section{in the magaxines}

In introducing the special U.N. section of The Corn respondent's Spring-Summer issue, editorial board member Saul Mendlovitz notes that "the twentieth anniversary of the United Nations is being celebrated" this year "in an atmosphere of doubt and uncertainty about the future of the world organization." Of course, he adds, "throughout its brief history only relatively few people have been willing to say that the U.N. is our only, or, indeed, our primary hope for preventing war and achieving peace." Indecd, "one need not be a sophisticated observer of international relations, steeped in historical sociology, power politics, or national interest theory to harbor such skepticism; in fact if one has pretensions and conceits in the academic world, it is almost essential to assume this position."

But what Mendlovitz finds "particularly disquieting today is that-with few exceptions-the liberal academic community itself; not to mention independent radical critics, no longer is willing to take the United Nations seriously."

Contributors to this special issue, says Mendlovitz, were asked "to consider the various facets of U.N. activity from a relatively radical perspective" to meet the obvious "need of a drastic and radical change in the present system of international relations." Among the essayists are Conor Cruise O'Brien, Louis B. Sohn, and Walter Goldstein.

\section{$\bullet$}

Maurice J. Goldbloom assesses President's Johnson's record to-date in the area of foreign affairs (Commentary, June) and pronounces "current American policy" to be suffering "from fundamental moral and ideotogical weaknesses which, if not peculiar to this Administration, are nevertheless more char. acteristic of it than of any of its recent predecessors."

Goldbloom attributes most of these weaknesses to "the frame of mind that may fairly be characterized as Achesonism." "The basis of Achesonism," he says, "is a frank advocacy of Reatpolitik in its grosscr forms. Mr. Acheson himself has publicly urged that American foreign policy be based on power rather than morality, and that the United States disregard world public opinion as a factor in determining its policies." But "unfortunately for the United States, 